\title{
Research on the Construction of the "Double Qualified" Teaching Staff Majoring in Information Technology in the Agricultural Universities
}

\author{
Hongjun $\mathrm{Gu}^{\mathrm{a}}$, Jinghui Wang ${ }^{\mathrm{b}}$, Lixin $\mathrm{Hou}^{\mathrm{c}}$ and Shijun $\mathrm{Li}^{\mathrm{d}^{*}}$ \\ Jilin Agricultural University, Changchun 130118, Jilin, China \\ aghj_dennis@163.com, b346056461@qq.com, ${ }^{\text {C16665299@qq.com, }{ }^{d} I s j 0883 @ s i n a . c o m ~}$
}

Keywords: Double qualified; Application type; Agricultural universities; Teaching staff construction

\begin{abstract}
Constructing the "double qualified" teaching staff is much important to agricultural universities. This paper constructs the "double qualified" teaching staff from the major of information technology, analyzes the problems in the traditional teaching objective orientation and teaching method of colleges and puts forward its cultivation mode and method. Taking the construction of the "double qualified" teaching staff majoring in information and technology in Jilin Agricultural University as an example, this paper gives specific implementation schemes and partial achieved results. This paper has a guiding role in the construction of the "double qualified" teaching staff for the information technology majors in agricultural universities.
\end{abstract}

\section{Introduction}

In February 2016, the Department of Higher Education of the Ministry of Education issued the notification which is "The Work Points of the Department of Higher Education of the Ministry of Education in 2016". In the structure of further optimizing talent cultivation, it points out that the general eligible undergraduate colleges should be promoted to shift to the application-oriented colleges. Also, colleges with industrial features should be supported to persistent in the demand orientation and cultivate professional talents with background knowledge and practical ability. The general target orientation of running a school of Jilin Agricultural University is that the advanced multi-disciplinary teaching and researching universities in our country, which take agriculture as the feature and face the local economy and social development, should be constructed. The orientation of talent cultivation target is that the applied, compound and research-oriented talents with solid foundation, broad vision, strong comprehensive quality and strong innovation ability should be cultivated. As for the information major of Jilin Agricultural University, it takes the agricultural information the characteristic, takes the cultivation of applied talents as the target and pay attention to the cultivation of the ability of engineering application and the comprehensive quality of students. The construction of "double qualified" teaching staff is the strong safeguard for cultivating high quality applied talents. "Double qualified" teachers refer to the teacher who cannot only successfully complete the theoretical teaching task, but also guide students in practice. They coincide well with the cultivation target of applied talents.

With the deepening of the reform, many colleges are constructing "double qualified" teaching staff and there are also a lot of literatures in this field. Yi Zhang and others have summarized the experience of constructing the "double qualified" teaching staff [1]. Zhonghua Wang has elaborated the urgency, existing predicament and outlet of the construction of the "double qualified" teaching staff in local ordinary colleges [2]. Hongzhi Wang and others have discussed the construction mode of "double qualified" teaching staff based on the cooperation between school and enterprise and analyzed the mode [3]. Yingjing Guan and others have discussed that establishing an excellent "double qualified" teaching staff is an important problem which needs to be solved urgently for cultivating excellent engineers [4]. Yanji Zhang and others have elaborated the basic conditions and training mechanism which "double qualified" teachers should possess and also elaborated the concept, feature, incentive system and safeguard measures of the construction schemes of teaching staff [5]. Yan Li has analyzed the significance and existing problems of the construction of "double qualified" 
teaching staff and put forward some countermeasures to strengthen the construction of "double qualified" teaching staff in application-oriented universities [6].

Information technology and related agricultural subjects should be combined. The communication of the teachers who major in information technology and the teachers who major in related agriculture, mechanical engineering and automation should be enhanced. The professional teachers should be encouraged to guide students to work in the enterprise to improve students' practical ability [7-10]. This paper analyzed the necessity, cultivation mode and practice measures and partial achieved results of the construction of "double qualified" teaching staff.

\section{The Necessity of the Construction of the "Double Qualified" Teaching Staff}

With the continuous update and progress of information technology, the talent market has undergone profound changes in the requirements of the current talent, the difficulties of graduate employment continue to increase and the quality of employment has declined. However, production service in the first line lacks applied talents. Many college talent cultivation modes can't keep pace with the demand of the adjustment of economic structure and industrial upgrading. In October 2015, the Ministry of Education, National Development and Reform Commission and the Ministry of Finance jointly issued the "Guiding Suggestions of Guiding Partial Local General Undergraduate Colleges to Shift to the Application-Oriented Colleges". It requires to enhance the construction of "double qualified and dual-talented" teaching staff to reform the innovative spirit and promote the transformation development of partial general colleges.

With the progress of science and technology, the update of talent cultivation scheme of many colleges lags behind the speed of social progress. The traditional teaching target orientation and teaching methods can't meet the cultivation mode of application-oriented talents. For the major of information technology, the relevant knowledge which is taught in theoretical classroom is relatively backward and disconnects with the advanced technology. Some software used in the experimental class has been eliminated in some good companies or factories. In the process of professional evaluation of colleges, the school attaches much importance to science and technology research, despise teaching, pay excessive attention to the quantity and quality of article publishing and doesn't work out the standard for teaching work, which lead to the decline of classroom quality and affect the talent cultivation quality of colleges. Meanwhile, the teachers just stick to the college and have no enterprises' practical experience and an international view, which restricts the cultivation of applied talents. After the employment of students, the poor basic theory and weak practical ability will inevitably bring employment problems, and even the graduation will be tantamount to unemployment. Thereby, this needs to change ideas, build "double qualified" teaching staff and change direction to the cultivation of application-oriented talents. Some opinions are given as follows about the construction of "double qualified" teaching staff in agricultural colleges and universities.

\section{The Cultivation Mode of the "Double Qualified" Teaching Staff Majoring in Information Technology}

Taking the science and technology competitions and science and technology innovation funds and projects as the platform. For information technology majors, science and technology competition is an important carrier for training teachers' practical ability. It can expand the teacher's knowledge, break the limitation of the inherent mode of thinking. The theory guides the practice and then the practical experience is fed back to the teaching, thus the teaching quality can be improved, the teachers can serve for the scientific research better and the virtuous circle can be formed. The science and technology innovation funds of college students and the national / provincial college students' innovation and entrepreneurship projects are taken as a platform to promote the universities to change the teaching idea, reform talent cultivation mode, strengthen the training of the ability of innovation and entrepreneurship, enhance the innovation and entrepreneurship consciousness of college teachers 
and lay a good foundation for the future entrepreneurship of college students so as to promote employment.

Taking the Short-Term On-the-Job Training and Studying Abroad of teachers as the platform. The short-term on-the-job training of teachers is an effective shortcut to improve the ability of combining the theory with practice and also the important link to construct the "double qualified" teaching staff. The overall theoretical level of college teachers is very high but they lack the ability of practical engineering training. Schools need to work out the relevant preferential policies to let the professional teachers lead students to get out of school and get exercise in the enterprise so as to enhance their practical ability. At the same time, the school should break the restrictions of the professional title, create more opportunities and conditions for teachers, send outstanding young teachers to study abroad to learn foreign advanced teaching ideas and practical engineering experience and broaden their horizons, and also blaze a trail for the construction of the "double qualified" teaching staff.

Taking the Project Which Combines the Information Technology and Agriculture as the Platform. Teachers should be organized and encouraged to apply for the relevant projects which combine the information technology and agriculture to give full play to the advantages of information technology in agriculture. The interinfiltration of cross disciplines can stimulate teachers' practice interest and impetus and provide help for the modernized agriculture. The communication, cooperation, mutual learning and progress among the teachers majoring in information technology, teachers majoring in agriculture and teachers majoring in mechanical automation should be enhanced. Meanwhile, teachers should form a team, have their own strengths and develop their abilities in the project.

Taking the Cooperation between Universities and Enterprises as the Platform. The cooperation between universities and enterprises plays an important role in the construction of "double qualified" teaching staff. Schools and enterprises should cooperate and sign a contract that in the premise of not affecting the school running and enterprises operation, school assigns teachers to lead students into the enterprise to visit, study and grasp the needs of enterprises in talent and technology to accumulate experience for the follow-up talent cultivation and clear the direction. Teachers and students can also directly participate in the practical activities, exercise their own practical ability, improve their practical spirit and offer suggestions for enterprises. Schools may employ experienced technical backbone of enterprises to come to school to undertake theoretical and experimental teaching work, make technical reports, participate in the revision of talent cultivation schemes and participate in the teaching reform and the compilation of teaching materials. The cooperation between universities and enterprises can also realize the win-win benefit between universities and enterprises and provide a favorable platform for the construction of the "double qualified" teaching staff.

Taking the Incentive Policy of the School as the Strong Guarantee. The incentive policy of university is a strong guarantee for the construction of "double qualified" teaching staff. The college should establish the confirmation system which is facilitate to the growth of "double qualified" teachers, provide the corresponding allowance for professional teachers in the process of cultivation, admit the results acquired during the part-time job in enterprises and give the corresponding consideration of policy in the process of professional evaluation. Also schools should set up some "double qualified" teachers model, give certain rewards and promote more teachers to participate in it, so as to promote the faster and better development of the construction of the "double qualified" teaching staff.

\section{The Practice Measures and Partial Results of the Construction of "Double Qualified" Teaching Staff in the Institute of Information Technology}

Science and Technology Competitions and Science Innovation Funds and Projects. The teachers who major in information technology guide students to participate in many science and technology 
competitions in our college [5]. The main competitions are: The "Challenge Cup" National Extracurricular Academic Science and Technology Competition for University Students(Big Competition), The "Challenge Cup" Extracurricular Academic Papers Competition for University Students (Small Competition), National/Provincial Electronic Design Competition for University Students, National "Freescale" Cup Smart Car Competition for University Students, National/Provincial Math Modeling Competition for University Students, National Internet of Things Design Competition for University Students, China "Internet + " Innovation and Entrepreneurship Competition for University Students, ACM International Program Design Competition for University Students and other school level science and technology competitions. The school league committee and dean's office actively publicize these science and technology competitions and invite technical backbone teachers in Information College to explain each competition. Thus, teachers and students can sort out their ideas and prepare the competition actively. In the past three years, the number of competition teams has increased year by year, the number of instructors has also increased and the results have become better and better. These competitions have trained the practical ability of the professional teachers, enhanced the theoretical study, earned the honor for school and cultivated a batch of students with innovation and entrepreneurship.

24 science and technology innovation fund projects of information technology institute have been evaluated in school level in 2015 . The proportion is more than $25 \%$ of the total. 14 national/provincial college students' innovative entrepreneurship training projects have been approved. The proportion is around $23 \%$ of the total. The amount and quality of papers and patents that are written by students instructed by teachers are increased greatly. 55 institute's science and technology innovation fund projects have been declared in 2016. The proportion is more than $30 \%$. The amount of instructors is increasing constantly. At the same time, quality of papers is increasing constantly.

Short-Term On-the-Job Training and Studying Abroad. In recent years, the amount of people who take part in on-time-job and study abroad is increasing constantly. Especially, doctors who graduated soon pay much more attention to studying abroad. Institutes send young backbone teachers to Beijing to join relevant advanced training courses for large data, Internet and virtual reality for many times. Institutes send teachers to Tsinghua University to do scientific research projects for many times. Institutes send teachers to universities in Taiwan to do academic exchange. Institutes send teachers to be visiting scholars in universities of Italy and New Zealand. Teachers who finished training would do keynote speech, report harvest and ideas about the future so that enthusiasm of other teachers' can be motivated. The center for teachers' teaching and development was established in June 2014. The first construction institute of the center for teaching and development of teachers was approved in Jilin province. This institute will be in charge of foreign visiting study, overseas study, foreign visiting study and long-term further education, participation in international conferences, domestic short-term training, school training, and social practice and so on. These can satisfy the needs of teachers' personalized development and provide support for the construction of "double qualified" teaching staff.

Combination of Information Technology and Agriculture. Characteristics of college development are the combination of information technology and agriculture. Teachers in information technology institute communicate with professional teachers who are from the institute of engineering and technology, the institute of resources and the environment, the institute of Chinese medicine, the institute of agriculture, and the institute of animal science and technology. They declared projects jointly and put information technology into practical agriculture. Led by leadership in the institute, teachers visited the ginseng fields in Jingyu county, the greenhouses and deer fields in the suburbs in Changchun, Funing Rabbit Industry limited company in Shenyang, agricultural expo garden in Changchun and other places. Teachers declared more projects relating to agriculture combined with the actual situation. For example, there are some projects of Education Department in Jilin, which are research on seeding detection of corn precision seeding machine and leak seeding system, research and application on farmer's greenhouse monitoring system in Jilin province based on the Internet and research on standardized breeding systems of cultured rabbit based on the Internet. 
There are also some Financial Department World Bank loan projects, which are research and application on facility vegetable safety production technology based on the Internet and so on. The same characteristics of these projects are the combination of information technology and agriculture. Meanwhile, these projects improved practical ability of teachers majoring in information and provided practice chances for "double qualified" teaching staff.

Cooperation between Universities and Enterprises and Social Practice. Information technology institute in Jilin Agricultural University signed an agreement with Chinasoft International group on joint cultivation of talents between universities and enterprise. It means that the institute can recommend teachers and students to Chinasoft International group to practice or recommend graduates to Chinasoft International to work. The institute widened ways of running universities, innovated talent cultivation mode, strengthened practical teaching link and improved quality of talent cultivation through the joint establishment of the teaching resources. In 2015 summer vocation, the institute has established 38 social practice groups. The groups are led by professional teachers to practice under social situation. For example, Sky Scenery Food Co., Ltd (signing an cooperation agreement with Jilin Agricultural University) in Jilin, Comprehensive Agricultural Information Service Co., Ltd in Jilin, Tonglian Technology Co., Ltd in Changchun, the Academy of Agricultural Sciences of Jilin province, Baoxin Network Information Co., Ltd in Jilin Province, SIPO Technology Co., Ltd in Jilin Province, Yingqi Technology Co., Ltd in Changchun, Funing Rabbit Industry Co., Ltd in Shenyang and so on. These social practice activities have trained the practical ability of teachers and students and also promoted the construction of "double qualified" Teaching staff.

Incentive Policy of University. The university enacted "The Teaching Achievement Appraisal and Award Method of Jilin Agricultural University", "The Method of Rewarding the Course Construction" and "Teaching Material Rewards Management Method" so that the university can give teachers who get different rewards correspondent award. Younger teachers who are studying for Master's degree and Doctor's degree can apply for the Youth Fund of the university (Masters can apply for $¥ 20000$, Doctors can apply for $¥ 30000$ ). More preferential policies were released for teachers who can transform results at company. At the same time, universities encouraged professional teachers to companies to enrich themselves in practice so that teachers can seek ways for employment of university students.

\section{Conclusion}

This paper analyzed how to establish "double qualified" teaching staff from necessity, cultivation mode and practice measures. Cultivation mode will be mainly stated in detail from five aspects, which is the science and technology competitions and science and technology innovation funds and projects, short-term on-the-job training and studying abroad, combination of information technology and agriculture, cooperation between universities and enterprises and social practice and incentive policy of universities. Part of research results was shown taking the information technology major in Jilin Agricultural University as an example.

\section{Acknowledgements}

The authors wish to express their gratitude to the projects: "12th Five-Year" Education and Science Planning Subjects of Jilin Province (No. GH150208, No. GH150206, and No. ZC13054), and Key Educational Reform Subject of Jilin Agricultural University (No. 2015xjzd27) for their generous support of this work.

\section{References}

[1] Y.Zhang, W.L.Sun and L.Wang: Journal of Agricultural University of Hebei, Vol.17 (2015), No.1, p.46. (In Chinese)

[2] Z.H.Wang: Journal of Nanchang Normal University, Vol.37 (2016), No.2, p.41. (In Chinese) 
[3] H.Z.Wang, J.N.Wang, L.J.Zhang, ect: Journal of Changchun Institute of Technology, Vol.16 (2015), No.1, p.119. (In Chinese)

[4] Y.Q.Guan and L.B.Zou: Heilongjiang Researches on Higher Education, 2015, No.1, p.106. (In Chinese)

[5] Y.J.Zhang and Y.M.Han: Journal of Baicheng Normal University, Vol.30 (2016), No.3, p.77. (In Chinese)

[6] N.Liu and J.H.Zhao: Microcomputer Application, Vol.32 (2016), No.9, p.35. (In Chinese)

[7] Y.J.Qiang and C.H.Xia: Education Teaching Forum, 2015, No.38, p.16. (In Chinese)

[8] Chao Jiang and Chunfang Zhu: Journal of Higher Correspondence Education, Vol.24 (2011), No.1, p.22. (In Chinese)

[9] Y.L, H.Q.Xue and H.B.Chen: Western China Quality Education, Vol.2 (2016), No.5, p.24. (In Chinese)

[10] H.J.Gu, H.Gong, S.J.Li, etc: Industrial and Science Tribune, Vol.14 (2015), No.20, p.159. (In Chinese) 